\section{Jednostka nowoczesna, człowiek kulturalny. O drukowanym poradnictwie dla młodzieży w latach 70.'}

\section{Anna Zawadzka}

TEKSTY DRUGIE 2019, NR 3, S. 126-147

DOI: 10.18318/td.2019.3.8 | ORCID: 0000-0002-6043-3321

$\mathbf{N}$ a lata 70. XX wieku w Polsce przypada boom poradnictwa. Skierowane głównie do młodzieży i dotyczące życia w wymiarze indywidualnym, poradnictwo to przybiera różne formy. Czasopisma młodzieżowe tamtego okresu instruują nastolatki, jeśli chodzi o wybór szkoły i zawodu, pouczają, jak zachowywać się kulturalnie, odpowiadając na pytania czytelników/czytelniczek, prowadzą rubryki poświęcone zdrowiu i seksualności. PRL-owski rynek wydawniczy lat 70. obfituje w poradniki książkowe na temat higieny, savoir-vivre'u, relacji międzyludzkich, życia seksualnego i rodzinnego, planowania aktywności, także w trybie dobowym. Do szkół podstawowych i ponadpodstawowych wprowadzone zostają lekcje poświęcone przysposobieniu do życia w rodzinie socjalistycznej i podręczniki z zakresu higieny. Wszystko to znajduje odbicie w socjologii: $\mathrm{w}$ drugiej połowie lat 70. uwagę badaczek/badaczy coraz częściej przyciągają

\section{Anna Zawadzka - doktor socjologii, pracuje w Instytucie Slawistyki Polskiej Akademii Nauk. Zastępczyni redaktor naczelnej „Studia Litteraria et Historica". Ostatnio opubliko- wała m.in. Zanikanie komunizmu w PRL-u. Przypadek dyskursu o inteligencji (2018). Współautorka tomu zbiorowego Opowieść o niewinności. Kate- goria świadka Zagłady w kulturze polskiej (1942-2015) (2018). Kontakt: annaza- wadzka@poczta.fm}

1 Za cenne uwagi, które otrzymałam podczas pracy nad tym tekstem, dziękuję Elizie Szybowicz i Pawłowi Ramsowi. 
postawy i wartości młodzieży, jej sposoby uczestnictwa w kulturze i spędzania wolnego czasu.

W niniejszym artykule spróbuję postawić pewne tezy na temat tego, po co potrzebne było wyżej opisane poradnictwo oraz wyrazem jakiej formuły socjalizmu były proponowane w obrębie poradnictwa lat 70. praktyki i postawy. W tym celu opiszę, jakie sfery życia obejmuje poradnictwo lat 70. oraz co jest w nim zalecane młodym ludziom, a co piętnowane jako naganne. O trzech aspektach, które współtworzą kontekst funkcjonowania tego poradnictwa, chciałabym wspomnieć już na wstępie.

\section{Modernizacja, urbanizacja, awans}

Po pierwsze, mam na myśli modernizację, rozumianą najbardziej dosłownie. Do lat 70. życie codzienne w PRL-u podlega licznym, powszechnie wprowadzanym i znaczącym udogodnieniom, takim jak zindywidualizowany dostęp do elektryczności, ciepłej wody i toalet, możliwość korzystania z transportu publicznego, publicznej służby zdrowia (przychodnie, szpitale, pogotowie) oraz ubezpieczeń zdrowotnych i emerytalnych. Uprzemysłowienie i nowe technologie produkcji wymagają z kolei nie tylko nowego typu organizacji pracy, ale także nowych sposobów niwelowania ryzyka. Zasady BHP, ośmiogodzinny dzień pracy, wczasy pracownicze, objęcie ubezpieczeniem zdrowotnym rodziny pracownicy/pracownika - to tylko niektóre sposoby zarządzania nim. Wszystko to, po pierwsze, ułatwia i wydłuża życie na poziomie indywidualnym, po drugie, racjonalizuje koszty państwa w opiece nad obywatel(k) ami, po trzecie, udostępnia szeroko rozumianej władzy nowe narzędzia kontroli i ewidencji. A także, co równie ważne, wszystko to wymaga od jednostek nowych umiejętności, nawyków, sposobów codziennego funkcjonowania.

Po drugie, połączona z socjalistycznym projektem zmiany struktury klasowej społeczeństwa, modernizacja oznacza awans². Awans zarówno

2 Jako projekt i jako zjawisko, awans w społeczeństwie egalitarnym to sprawa ambiwalentna. Możemy bowiem mówić o co najmniej trzech rodzajach awansu: w obrębie jednej klasy, międzyklasowym i wreszcie zniesienia szczebli, po których jednostka wspina się i awansuje. Wygląda na to, że PRL przeszedł ewolucję od opcji ostatniej do dwóch pozostałych, niejako rezygnując z komunizmu, którego niezbywalnym postulatem było zniesienie społeczeństwa klasowego. W wymiarze międzypokoleniowym ambiwalencję tę dobrze oddają słowa narratora powieści Tanczq̨cy jastrząb. Narodziny syna głównego bohatera - chłopa, który po 1945 roku przeprowadził się ze wsi do miasta, poślubił kobietę z tzw. dobrej rodziny i został inżynierem - komentuje on tak: „Ale kto na kim się zemścił, kto zwyciężył, gdy urodził się ten skrzeczący pędrak [...]. Czy zwyciężyli tamci twoi z monotonnej doliny, rozciągającej się między dużą rzeką 
w wymiarze indywidualnym, jak i całych grup społecznych. Awans ów wymaga pomocy w zdobyciu określonych kompetencji klasowych osobom dotąd ich pozbawionym. Kompetencji przejawiających się w życiu codziennym, związanych z tzw. kulturą osobistą oraz manifestowanych w sposobie korzystania $\mathrm{z}$ oferty kulturalnej.

Trzecim istotnym czynnikiem jest urbanizacja. Podobnie jak dwa poprzednie, w wymiarze jednostkowym urbanizacja powoduje nieraz radykalną zmianę stylu życia jednostek w stosunku do pokolenia rodziców. Zmiana ta skutkuje osłabieniem skuteczności przekazu pokoleniowego, a czasem nawet jego zerwaniem. W warunkach przyspieszonej modernizacji wzory życia poprzednich pokoleń stają się dla młodych ludzi bezużytecznym źródłem wiedzy.Tracą przynajmniej część akulturacyjnego potencjału. Potrzebne są więc nowe źródła socjalizacji. Nowi wychowawcy do spraw najbardziej oczywistych, ponieważ to właśnie zaklęte w rutynie oczywistości ulegają dynamicznym przemianom. Toteż w latach 70. pojawią się nie tylko poradniki dla młodzieży, ale także dla rodziców. Traktują one o tym, jak wychowywać młodzież, a przy okazji mogły pełnić funkcję wychowawczą wobec czytających je dorosłych ${ }^{3}$.

Niniejszy tekst opiera się m.in. na kwerendzie dwóch czasopism: „Filipinki” i „Nowej Wsi”. Oferta prasowa dla młodzieży była w latach 70. bardzo szeroka, dlatego wybór tych dwóch tytułów wymaga uzasadnienia. W książce Paradoksy młodzieżowe z 1970 roku Mikołaj Kozakiewicz analizuje pięć czasopism młodzieżowych: „Dookoła świata”. „Filipinkę”, „Na przełaj”, „Nową Wieś" i „Radar"'. Bierze na warsztat rocznik 1966 wymienionych periodyków. „Filipinkę”, mimo uwag krytycznych, uważa Kozakiewicz za pismo najlepiej wypełniające zadania wychowawczo-edukacyjne, które nie schlebia gustom

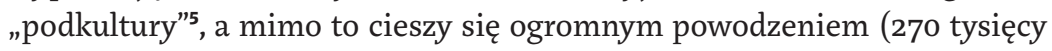

a górą kamieniołomu, i ten twój szalony starzec, porażony na swoim, dawniej dworskim polu, i wszyscy podobni do niego szaleńcy porażeni szczęściem po otrzymaniu darów czasu, czy oni dokonywali zemsty, czy ci panowie z miast i fabryk i ich szaleńcy porażeni nieszczęściem po stracie tych fabryk i folwarków? Kto zwyciężał i co zwyciężało, i kto na kim się mścił, i kto kogo wypychał, i jakie dzieje, i jaka historia zwyciężała w tej walce, rozpoczętej już w tym galaretowatym drobiazgu, który wyrośnie na twojego syna Jerzego [...]?" (J. Kawalec Tańczq̨cy Jastrząb, PIW, Warszawa 1988, s. 99). To jednak temat na osobny tekst.

3 Zob. np. A. Jaczewski O dojrzewaniu, Wydawnictwa Szkolne i Pedagogiczne, Warszawa 1974. M. Kozakiewicz Paradoksy młodzieżowe, Książka i Wiedza, Warszawa 1970.

5 Terminem tym Mikołaj Kozakiewicz określa kulturę młodzieżową, trendy i mody, za emblemat których autor uznaje big-beat. Teoretycznie stosuje on pojęcie podkultury opisowo, ale pobrzmiewa w tym określeniu pejoratywny akcent. 
limitowanego nakładu) i odzewem ze strony czytelniczek w postaci listów do redakcji. Jego zdaniem „Filipinka” ma największe zacięcie pedagogiczne i wyraźną ambicję wychowawczą. Kozakiewicz chwali m.in. to, że „Filipinka” skupia się na obalaniu zabobonów i niejednokrotnie ruga czytelniczki za dawanie wiary przesądom. Kozakiewiczowi brakuje w „Filipince” poruszania tematów kontrowersyjnych, drastycznych i dramatycznych (np. z zakresu seksuologii) oraz dotyczących sporów młodzieży z rodzicami, mimo to uważa on „Filipinkę" za "pismo najbardziej świadome swojego programu i zadań". Kozakiewicz uważa także, że „Filipinka” jest pismem obejmującym niemal całą grupę wiekową, bez względu na miejsce zamieszkania i pochodzenie. Grupą tą są dziewczęta w wieku 16-2o lat? . Na rzecz „Filipinki” przemawia także fakt, że pismo to, przeznaczone dla nastolatek, cieszyło się od początku istnienia (1957) ogromną popularnością, pełniąc przede wszystkim funkcję poradniczą ${ }^{8}$. Alina Łysak pisze, że listy od czytelniczek stanowiły podstawę „Filipinki": korespondencja kwitła na łamach czasopisma i poza nim, ponieważ autorki „Filipinki” odpisywały czytelniczkom także prywatnie. Niektóre z piszących zostawały z kolei autorkami pisma. Podobnie jak na łamach „Nowej Wsi”, na listy publikowane w „Filipince” odpisywali nie tylko redaktorzy, ale także inni odbiorcy pisma, co owocowało nieraz dyskusjami ciągnącymi się przez wiele numerów⿳⺈.

Główny dział poradniczy „Filipinki” - Jak się zachować radzi Ewa - powstał w 1969 roku. Pod nazwą Jak się zachować funkcjonował także wcześniej, ale w formie ograniczonej. W 1966 roku drukowany był na łamach dwutygodnika 12 razy, tymczasem od początku lat 70. był zamieszczany w każdym numerze. W 1976 roku pojawia się w „Filipince” rubryka Listy poufne, na które odpowiada - najczęściej artykułem na całą stronę - osoba podpisana jako „Powierniczka”. W tym samym roku rubrykę Jak się zachować radzi Ewa zastępuje rubryka Ada to nie wypada prowadzona przez Adelinę. Jednocześnie cały czas drukowane są rubryki: Poczta Bożeny oraz Rady dla każdej z was - obie oparte na listach od czytelniczek. Wreszcie, w 1976 roku „Filipinka” rozpoczyna cykl: Elementarz Psychologiczny. Pierwszy artykuł z tej serii nosi tytuł: Potrzeby

6 M. Kozakiewicz Paradoksy, s. 57-59.

7 Tamże, s. 60.

8 A. Łysak Poradnictwo na łamach „Filipinki”, w: Edukacja, wychowanie, poradnictwo w kulturze popularnej, red. M. Kondracka, A. Łysak, Biblioteka UWr, Wrocław 2009, s. 128.

9 Tamże, s. 132-133. 
psychiczne, drugi: Motywy i postawy, trzeci: Emocje. Zacięcie wychowawcze czasopisma pobrzmiewa także w tonie, w jakim pisane są artykuły nie będące stricte poradniczymi. Często mają one charakter protekcjonalnego pouczenia lub łagodnej perswazji.

Z kolei czasopismo „Nowa Wieś” proponowało nowoczesny styl życia młodym ludziom mieszkającym na wsi. Zamiast przedstawiać miasto jako jedyną przestrzeń, która oferuje wartki nurt współczesności i dostęp do kultury, tygodnik „Nowa Wieś” wszystko to próbował zaszczepiać poza obiegiem miejskim. Przynosił wzory modernizacyjne na wieś. Oferował swoim czytelniczkom i czytelnikom nową tożsamość: zaznajomionego z nowinkami, obytego kulturalnie, ale dumnego ze swojego pochodzenia i pracy na roli mieszkańca wsi. Czasopismo instruowało więc w zakresie zdrowia, higieny, mody, urody, seksualności, savoir-vivre'u, kontredansu i codziennych przyzwyczajeń, poszerzając tym samym krąg zobowiązanych, by z instrukcji tych korzystać, o mieszkanki i mieszkańców wsi, a jednocześnie - przynajmniej deklaratywnie - biorąc pod uwagę specyfikę wiejskiego życia i pracy na roli. W latach 70. na łamach „Nowej Wsi” rubryki z listami od czytelników i odpowiedziami redakcji - Jak się zachować, Księ$\dot{z y c}$, ty i ja, Co o tym myślicie?, kącik towarzyski - wypełniają każdorazowo dwie strony tygodnika.

\section{Racjonalny tryb życia}

Zakres porad, który chciałabym pokrótce omówić, to zdrowie i higiena ${ }^{\mathbf{1 0}}$, savoir-vivre, przestrzeganie społecznych hierarchii i damsko-męski kontredans. Znacząca część poradnictwa lat 70. jest jednak mniej sprecyzowana. Dotyczy czegoś, co można by nazwać „racjonalnym trybem życia”.,Racjonalny tryb życia - to przede wszystkim regularne wykonywanie przez człowieka codziennych obowiązków, zarówno zawodowych, jak i pozazawodowych. [...] Należy przewidzieć odpowiednią liczbę godzin na sen, ustalić czas przyjmowania posiłków, zaplanować pracę zawodową (bądź szkolną) i domową, obmyślić wystarczający i dobrze zorganizowany wypoczynek dzienny oraz pobyt na świeżym powietrzu" - tak termin ten wyjaśniali autorzy szkolnego

10 W niniejszym tekście nie analizuję poradnictwa seksuologicznego, a jedynie to, które wpisywało seksualność w zakres higieny i zdrowia młodzieży. O poradnictwie seksuologicznym lat 70. zob. A. Kościańska Seks, przyjemność i przemoc. Kształtowanie wiedzy eksperckiej o seksualności w Polsce, Wydawnictwa UW, Warszawa 2014. 
podręcznika do higieny"1. Posłużyli się nim także Wanda Kobyłecka i Andrzej Jaczewski w wielokrotnie wznawianym poradniku $O$ dziewczętach dla dziew$c z a t^{12}$. Książka ta uczy o tzw. dojrzewaniu płciowym, ale „Rozdział 6, który jest właściwie tylko dodatkiem i przynosi jeszcze kilka rad” poświęcony jest tematom takim, jak: wstawanie, mycie się, gimnastyka, ubieranie, jedzenie, oddychanie, droga do i ze szkoły, zachowanie w szkole, odrabianie lekcji, czas wolny, wieczór, wypoczynek, prawidłowe siedzenie, stanie i chodzenie, wietrzenie pomieszczeń, miejsce do pracy, miejsce do spania, bielizna, przybory toaletowe, relaks, ilość, jakość i sposób jedzenia. Wśród lektur polecanych przez Kobyłecką i Jaczewskiego znajdują się poradniki na temat zachowania zdrowego wzroku, żywienia rodziny, efektywnych sposobów uczenia się, skutków palenia papierosów.

Część poradników dostarcza szczegółowych opisów praktyk codziennych. Omawia czynności oczywiste (jedzenie, picie, spanie, wypróżnianie), jak również wprowadza do repertuaru codzienności czynności nowe, przedstawiając je jako zarazem zwyczajne i konieczne (wietrzenie pomieszczeń, relaks, gimnastyka). Na przykład książka Ireny Krzeskiej Wyprawa po zdrowie przeznaczona dla dzieci z klas III-IV i będąca uzupełnieniem podręcznika Wiadomości o przyrodzie Hanny Obiezierskiej i Stanisława Ziemieckiego, zawiera rozdziały: Jedzenie i picie, Dlaczego żujemy pożywienie?, Jak dbać o zęby?, Praca, zabawa i odpoczynek, Alkohol i wypadki, Co daja ćwiczenia gimnastyczne, Właściwa odzież, Przestrzeganie czystości, Czyste włosy, Czyste ręce, Czyste zęby, Czystość całego ciała, Czysta odzież, Wjaki sposób pierze się skarpetki?, Wjaki sposób czyści się buciki?, Obyczaj czystości (rozdział o tym, by zasłaniać usta, gdy się kicha lub kaszle), Jadłospis tygodnia, Nakrywanie do stołu, Przy stole, Zmywanie naczyń, Trzeba oddychać świeżym powietrzem, Krótki odpoczynek, Spokojny wieczór, Mycie rąk, Wychodzenie za własna potrzeba, Wietrzenie, Jak dbać o włosy?, Jak dbać o ubranie?, Ogrzewanie klasy, Dobra postawa przy siedzeniu i staniu, Jak chodzić, Woda do picia, Rozmowa z lekarzem, Czyste sklepy, Kosze do śmieci, Szczepienia ochronne, Zdrowie narodu, Zdrowie ludzi na całym świecie, Wlesie, Na szosach itd. ${ }^{13}$

C.W. Korczak, J. Leowski Higiena dla klasy IV liceum ogólnokształcqcego, Państwowe Zakłady Wydawnictw Szkolnych, Warszawa 1970, s. 120-121. W. Kobyłecka, A. Jaczewski O dziewczętach dla dziewcząt, Państwowy Zakład Wydawnictw Lekarskich, Warszawa 1981. 
Porady o charakterze ogólnym znajdziemy także w książce $Z$ dnia na dzień dorośli Andrzeja Jaczewskiego ${ }^{\mathbf{1 4}}$. Poza informacjami o fizycznych i psychicznych objawach dojrzewania, Jaczewski umieszcza w książce rozdział pod znaczącym tytułem $O$ kulturalny stosunek do spraw ptci. Apeluje w nim, by rozmawiać o seksualności bez brutalności i chamstwa, darować sobie wulgaryzmy i dowcipy oraz szanować przyzwyczajenia i sprawy prywatne innych bez względu na to, jak nietypowe by się wydawały. W podobny sposób apeluje Ewa w filipinkowej rubryce Jak się zachować radzi Ewa. Wiele jej porad ma charakter ogólny. Poucza np., że nikogo nie wolno obrażać, nie należy spotykać się z chłopcami, którzy często bywają pijani, nie jest dobrze rozczulać się nad sobą, trzeba przełamywać własną nieśmiałość itd.

Ewa, Adelina i Grzesio - autorzy porad na łamach „Filipinki” i „Nowej Wsi” - często odwołują się do pojęcia „rozsądku”, które koresponduje z „racjonalnym trybem życia", do jakiego nawołują autorzy i autorki wspomnianych już podręczników. W jego zakres wchodzić będzie i higiena, i „kulturalne obycie”, ale oferowany przez poradnictwo przepis na rozsądny i racjonalny tryb życia to coś więcej. Stanowi on swoiste know how nowoczesnego podmiotu. Wskazuje, jak być osobą „na czasie”. W stworzonej na wzór słownika książce Jana Kamyczka (pseudonim Janiny Ipohorskiej) Savoir-vivre dla nastolatków z 1974 roku, w której znajdziemy niesamowicie drobiazgowe ujęcie codziennego życia, znajdują się hasła takie jak „nowoczesność” czy „na mieście”15. Bycie "prawdziwie nowoczesną osobą"16 jest w książce Kamyczka przedstawiane jako wielka wartość, podobnie jak bycie „światowym”17. „Jednostka nowoczesna prawdziwie to ta, która odpowiada bardziej kluczowym wymogom epoki obecnej i nadchodzącej. A zatem wiedza, etyka bez dawnej pruderii, orientacja w sprawach świata, odporność psychiczna i fizyczna, z konkretów na przykład znajomość języków obcych, posiadanie prawa jazdy, odpowiedzialny wybór zawodu" - pisze Jan Kamyczek. Dyskurs tego typu stwarza nowe normy i zarazem zawstydza tych, którzy jeszcze ich nie wdrożyli lub przynajmniej nie starają się tego zrobić. Drobiazgowo uczy dbania o siebie

14 A. Jaczewski Z dnia na dzień dorośli, Państwowy Zakład Wydawnictw Lekarskich, Warszawa 1979 . J. Kamyczek Savoir-vivre dla nastolatków, Wydawnictwo Harcerskie "Horyzonty”, Łódź 1974. Tamże, s. 144 . Tamże, s. 133. 
i zabiegów wokót siebie ${ }^{\mathbf{1 8}}$, jednocześnie zalecając młodym ludziom, by umiejętności te czynili elementami swojej tożsamości i budowali na nich poczucie własnej wartości. Zaleca nowe nawyki, implantuje nowe przyzwyczajenia.

Jeśli chodzi o poradnictwo lat 70., foucaultowską troskę o siebie w dużej mierze należy traktować dosłownie. Zalecenia dotyczące higieny opisywane są szczegółowo. Na przykład w artykule Przyjemność czy obowiazek, który ukazał się na łamach „Filipinki”, znajdziemy informacje, że ciało należy myć codziennie, włosy natomiast co tydzień, raz w tygodniu czyścić stopy pumeksem, obcinać skórki przy paznokciach, codziennie przed snem rozczesywać włosy, po szkole zaś umyć twarz oraz zmienić ubranie na domowe. Na setki pytań czytelniczek dotyczących właśnie takich spraw odpowiadano na łamach „Filipinki" w dziale Rady dla każdejz was. Były to najczęściej jednozdaniowe porady, poprzedzone wyboldowanym imieniem, nazwiskiem lub pseudonimem osoby pytającej.W rubryce tej znajdowały się informacje na temat codziennej pielęgnacji ciała, niepokojących objawów fizjologicznych, koniecznych wizyt lekarskich, kosmetyków, środków czystości. Z kolei w Książce dla chtopców ${ }^{19}$ Andrzej Jaczewski i J. Żmijewski higieną nazywają odpowiedni tryb życia w okresie pokwitania i uczą czytelników, na czym on polega. W rozdziale Jak może i powinno być namawiają, by chłopcy robili plan dnia, by przestrzegali kolejności odrabiania lekcji, by zachowywali odpowiednie proporcje między pracą a odpoczynkiem, by dbali o dobry sen. Higiena była także przedmiotem troski szkolnictwa. W wydanym po raz pierwszy w 1970 roku podręczniku Higiena dla klasy IV liceum ogólnokształcacego $0^{20}$ znajdują się rozdziały poświęcone kolejno: zdrowiu fizycznemu i psychicznemu, higienie pracy, higienie wypoczynku i rozrywki, higienie życia rodzinnego (w tym „popędowi płciowemu człowieka"), higienie życia społecznego oraz organizacji ochrony zdrowia. O tytułowej higienie autorzy piszą: „Higienę utożsamiany często z czystością ciała. Pogląd taki nie jest słuszny, gdyż czystość ciała stanowi tylko jeden z elementów higieny. Ma ona niewątpliwie wpływ na utrzymanie zdrowia, chociażby przez niedopuszczanie do wielu zakażeń. Przede wszystkim jednak czystość jest miernikiem kulturyludzi [wyróż. - A.Z.)”21.

18 Zob. M. Foucault Historia seksualności, przeł. B. Banasiak, T. Komendant, K. Matuszewski, Czytelnik, Warszawa 1995, s. 415-446.

A. Jaczewski, J. Żmijewski Książka dla chłopców. O dorastaniu i dojrzewaniu, Państwowy Zakład Wydawnictw Literackich, Warszawa 1973. 


\section{Człowiek dobrze wychowany}

Gros poradnictwa lat 70. - zarówno tego książkowego, jak i drukowanego na łamach czasopism - dotyczy właśnie owej „kultury ludzi”. Obycie umila życie to wydany w 1966 roku i wznowiony w 1973 roku poradnik Aliny Goldnikowej22. Skierowana do dziewcząt, książka Goldnikowej instruuje w zakresie kulturalnego zachowania w gościach, szkole i środkach miejskiego transportu, podczas świąt, na zabawie, wakacjach i potańcówce. Otwierające poradnik, w założeniu żartobliwe „Prawo jazdy uprawniające do prowadzenia pieszego pojazdu dwuśladowego; $\mathrm{w}$ domu, szkole, lokalach, na wizycie i ulicy - w dni powszednie i święta" z miejscem na podpis właścicielki książki, sugeruje, że do „obycia” należy między innymi czystość („twarz: domyta, pogodna”), schludność („włosy: zawsze uczesane”), serdeczność (,usta: skore do uśmiechu”) i dyskrecja („nos: nie wściubiony w cudze sprawy”). Niejeden poradnik z zakresu seksuologii zawiera przynajmniej rozdział poświęcony savoir-vivre'owi. Na przykład w książce W cztery oczy. Tylko dla dziewcząt Marii Dankowskiej znajdziemy rozdział Ja i dobre maniery ${ }^{23}$, a w książce Mikołaja Kozakiewicza Zanim staniecie się kobietami rozdział Wypada - nie wypada, wolno - nie wolno $^{24}$. Już w latach 6o. ukazały się poradniki z zakresu savoir-vivre'u skierowane do wyszczególnionych odbiorców: Kodeks narciarski czyli narciarski savoir vivre Władysława Lankiewicza i Andrzeja Rozmarynowicza ${ }^{25}$ oraz Savoirvivre dla sprzedawców Ireny Gumowskiej ${ }^{26}$. Na marginesie, $A B C$ dobrego wychowania tej samej autorki już w 1969 roku doczekało się szóstego wydania. Choć więc na lata 70. przypada wzmożenie dyskursu poradniczego, nie oznacza to, że wcześniej nie było na niego zapotrzebowania.

„Filipinka” i „Nowa Wieś” poświęciły savoir-vivre'owi osobne, interaktywne rubryki. W „Filipince” Ewa, a potem Adelina, w „Nowej Wsi” zaś Grzesio odpowiadali na listy czytelniczek i czytelników, rozstrzygali ich spory z rodzicami, sympatiami i rówieśnikami, doradzali, pouczali, wytykali gafy, chwalili za dobre maniery, ganili za złe zachowanie. W obu czasopismach

22 A. Goldnikowa Obycie umila życie, Nasza Księgarnia, Warszawa 1973.

23 M. Dankowska W cztery oczy. Tylko dla dziewcząt, Horyzonty, Warszawa 1973.

24 M. Kozakiewicz Zanim staniecie się kobietami, Państwowy Zakład Wydawnictw Literackich, Warszawa 1973.

W. Lenkiewicz, A. Rozmarynowicz Kodeks narciarski czyli narciarski savoir vivre, Wydawnictwo "Sport i Turystyka", Warszawa 1969.

26 I. Gumowska Savoir vivre dla sprzedawców, Zakład Wydawnictw CRS, Warszawa 1964. 
rubryki te miały charakter perswazyjny, jednak o ile na łamach „Nowej Wsi” Grzesio okazywał piszącej do niego młodzieży raczej cierpliwość, troskę i sympatię, o tyle Ewa i Adelina z „Filipinki” nierzadko traktowały autorki i autorów pytań obcesowo, nie ukrywając irytacji. Czasem odpowiadały w tonie połajanki, innym razem kpiarsko. Często ich odpowiedzi wydają się oschłe i kategoryczne.

Szczególnym przedmiotem pouczeń Ewy z „Filipinki” był poprawny język polski w mowie i piśmie. „Radziłabym ci popracować nad stylem i ortografią. Spójrz, ile błędów zrobiłaś w króciutkim liście!" - beształa autorkę pewnego listu ${ }^{27}$. „Dziewczyna, która chce uchodzić za kulturalną i obytą towarzysko, musi także umieć poprawnie mówić po polsku" - pouczała kolejną. Jeszcze inną, która zamiast „podszedł do mnie" napisała „wyszedł do mnie”, zawstydzała: „Naprawdę nie wypada, aby uczennica liceum używała takich zwrotów". Błędy gramatyczne i ortograficzne, a także niezręczności stylistyczne Ewa wpisywała w poczet złego wychowania. Definiowała je jako naruszenie zasad savoir-vivre'u. „Kulturalnego człowieka poznaje się także i po tym, że mówi ładną, nie zaśmieconą błędami polszczyzną" - pisała. W podobny sposób błędy językowe traktował Jan Kamyczek, który we wspomnianym już, zbudowanym na wzór encyklopedii poradniku Savoir-vivre dla nastolatków, hasło „Styl” w całości poświęcił językowi polskiemu oraz poradom, jakich zwrotów unikać w mowie i w piśmie.

Celem autorek filipinkowych porad było, by ich czytelniczki zachowywały się jak „człowiek kulturalny”. Tym pojęciem Ewa posługiwała się bardzo często, podobnie jak terminem „człowiek dobrze wychowany". Inne sformułowania o pozytywnej konotacji, których używała Ewa, to: „ludzie kulturalni”, "osoba coś sobą reprezentująca”, ,obycie towarzyskie”,,,dowód elegancji”. Maria Dankowska w poradniku W cztery oczy zachowania, które chwali, nazywa z kolei „ładnymi”. Gdy jakaś postawa spotykała się z dezaprobatą filipinkowej powierniczki, wtedy Ewa stosowała zwroty: „niekulturalny",,źle wychowany”, "gruboskórny”, „niewyrobiony towarzysko", „cham”, „dowód braku kultury”. Analogiczne epitety znajdziemy w poradniku Jana Kamyczka. Jednostka "o niezbyt dużych ambicjach”, a zachowanie „niestosowne”,"mało światowe”, „,z minionej epoki",,zbyt obcesowe”, ,nie twarzowe" i „nieatrakcyjne" - to tylko niektóre z określeń, za pomocą których Kamyczek wyraża dezaprobatę dla poszczególnych praktyk i piętnuje je jako niedopuszczalne.

27

Cytowane sformułowania Ewy i Adeliny pochodzą z rubryk Jak się zachować radzi Ewa oraz Ada to nie wypada, z numerów "Filipinki" wydanych w latach 1970-1979. 
W poradnictwie na łamach „Filipinki” "człowiek kulturalny" to przede wszystkim człowiek „taktowny”. Podobnie jak wymienione wyżej określenia "człowieka kulturalnego", „takt" - a także „dobre maniery" - nie zostają zdefiniowane. Co prawda porady Ewy pozwalają wyrobić sobie mgliste pojęcie, co owe pojęcia oznaczają - np. to, że nie należy być krzykliwym, nazbyt swobodnym, mówić i śmiać się głośno, intensywnie gestykulować, trzeba być cichą, grzeczną, delikatną, zachowywać się „dyskretnie i z miłym uśmiechem”, a także starać się nie sprawiać innym przykrości - jednak Ewa i Adelina używają tych określeń nie tyle w charakterze opisowym, co dystynktywnym. W podobny sposób Ewa posługuje się pojęciami "gustu" i „smaku": jako dezawuujących używa zwrotów typu „nieestetyczne zachowanie”, ,niesmaczne”, „w bardzo złym guście”, „nieapetyczne gesty”, „pretensjonalne”. Nie tłumaczy jednak, dlaczego w ten sposób klasyfikuje niektóre zachowania i co jest w nich niewłaściwego. Dylematy czytelnicze, które rozwiązuje, służą jej jako przykłady, za pomocą których buduje obraz idealnego podmiotu: młodego człowieka poruszającego się z łatwością i swobodą w setkach społecznych interakcji. Dlatego kategorie, których używa Ewa - „człowiek taktowny”,,osoba coś sobą reprezentująca”, ,dziewczyna wyrobiona towarzysko" - to kategorie tożsamościowe. Proponowane czytelniczkom i czytelnikom aspiracje identyfikacyjne.

Sposobem ich zaszczepiania jest przede wszystkim zawstydzanie. Już samo pojęcie „osoby niekulturalnej” niesie w sobie deprecjonujący ładunek. W prezentowanym jako atrakcyjny świecie „towarzyskiego wyrobienia”, do którego Ewa zaprasza i którego wymogów strzeże, człowiek „niekulturalny” to ktoś wart wyśmiania, delikwent gorszego sortu, niższej rangi. Rangę tę Ewa systematycznie obniża szyderczymi uwagami pod adresem tych, którzy zachowują się niezgodnie z zasadami savoir-vivre'u. Często stosuje pod ich adresem kategorie: „niedojrzały”,,,dziecinny”,,,smarkacz”,,,młodziutki”, co ma zapewne uderzyć w czułe punkty młodych czytelników. Nierzadko zmęczeni „upupianiem”, młodzi ludzie chcą być traktowani jak dorośli, czyli z szacunkiem i poważnie. Ewa zdaje się składać im obietnicę: miarą dojrzałości jest „obycie”, jeśli więc będziecie zachowywać się zgodnie z moimi wskazówkami, inni zaczną postrzegać was jak dorosłych.

Podobnie jak w poradnikach książkowych z zakresu savoir-vivre'u dla nastolatków, dyskurs Ewy (a potem Adeliny) zasadza się na gestach aprobaty i deprecjacji. Ewa, owszem, odnosi się do setek drobnych incydentów, doradzając i odradzając czyteniczkom i czytelnikom w konkretnych sprawach, wszystkie je jednak traktuje jako zaledwie materiał służący do 
zademonstrowania, co jest, a co nie jest odpowiednie, a zatem jaki jest, a jaki nie jest pożądany przez nią (kulturalny) człowiek. Zasady, które głosi i których wdrożenia domaga się od młodzieży, autorka porad prezentuje jako ponadczasowe, wobec tego obywają się one bez uzasadnienia. Ewa posługuje się zwrotami typu „wiadomo, że”, „wypada”, „nie ma powodu, by”, ,obowiązkiem jest”,,,rozsądek podpowiada”,„zgodnie z zasadą grzeczności”,,rycerski zwyczaj nakazuje”, ,kultura osobista wymaga" itd. W ten sposób każdorazowo buduje swoją rangę wyroczni i zarazem egzekwuje ją, oceniając, rozstrzygając, pouczając, rugając i chwaląc piszącą do niej młodzież. Ewa wypowiada się tonem nieznoszącym sprzeciwu i niedopuszczającym dyskusji, ponieważ takie właśnie wydają się zasady, na straży których stoi i których uczy: odwieczne, niezmienne, nie do podważania, lecz do przestrzegania. Ich niedochowanie naraża jednostkę na pozbawienie szacunku i upokarzającą śmieszność. O karze tej Ewa ostrzega, aprobuje ją i ją wymierza.

W jednym tylko poradniku z zakresu savoir-vivre'u znalazłam kontekstualizację i uhistorycznienie prezentowanych na jego łamach zasad. W książce Savoir vivre dla nastolatków hasło „Zwyczaje” Jan Kamyczek poświęca zmienności obyczajów w czasie i opisuje je jako swoisty znak komunikacyjny, przyznając, że wiele z nich nie ma innej racji bytu. Wartości savoir-vivre’u Kamyczek upatruje w fakcie, że „umożliwia porozumienie i dobre współżycie z otoczeniem". Nie tyle treść tego uzasadnienia wydaje mi się istotna, co sam fakt, że autor uznał je za potrzebne. W porównaniu z dyskursem poradnikowym „Filipinki” i „Nowej Wsi”, które to czasopisma wartość „kulturalnego obycia” i współczesnego im savoir-vivre'u wpisują w doksę, gest Kamyczka wydaje się nietypowy. Konteksualizacja, jakiej dokonuje autor poradnika, dotyczy także lokalnych i globalnych różnic w zakresie aprobowanych zwyczajów. Nawet w rodzinie koleżanki mogą obowiązywać inne zasady, przestrzega Kamyczek, a jeśli tak, to na czas pobytu u innych należy je przyswoić i ich przestrzegać. Kamyczek podkreśla jednak, że współcześnie, zwłaszcza w wymiarze międzynarodowym, zasady grzeczności ulegają daleko idącej unifikacji i uniwersalizacji, a zatem wzrasta wartość ich przyswojenia.

\section{Rycerskość, honor, praca}

W świetle założeń projektu, jakim była u swego zarania Polska Rzeczpospolita Ludowa, wszystko to dziwi. Więcej: jawi sięjako odejście od komunistycznych postulatów i zaprzepaszczenie osiągnięć komunistycznej rewolucji. Jako nurt filozofii społecznej, komunizm oparł się na uhistorycznieniu tego, co przez 
ideologie podtrzymujące rozmaite systemy nierówności - chrześcijaństwo, feudalizm, kapitalizm - prezentowane było jako odwieczne. Na ujawnieniu partykularności tego, co wydawało się uniwersalne. Na umożliwieniu myślenia o zmianie tego, co jawiło się jako raz na zawsze dane. Tymczasem poradnictwo, o którym mowa, na nowo odhistorycznia partykularną cechę jednej klasy, nadając „kulturalnemu obyciu” walor uniwersalnej i obywającej się bez uzasadnienia wartości. Po drugie, wartość jednostek proponuje oceniać na podstawie ich stylu życia i wyborów estetycznych, za wzór stawiając posiadaczy dziedziczonego klasowo szlachectwa kulturowego, czyli w gruncie rzeczy posiadaczy pewnego rodzaju kapitału. Po trzecie, zawstydza i piętnuje tych, których habitus klasowy jest inny niż mieszczański. I wreszcie, po czwarte, przywraca hierarchie, które komunizm deklaratywnie odrzucił, demaskując stojącą za nimi przemoc symboliczną. Innymi słowy, próbując zasypać przepaść między klasami, poradnictwo wikła się w paradoks, ponieważ zarazem ustanawia habitus jednej z klas dominujących jako model do naśladowania i przedmiot aspiracji.

Hierarchie, którym hołduje omawiane tu poradnictwo z lat 70., to przede wszystkim pierwszeństwo starszych przed młodszymi, rodziców przed dziećmi, nauczycieli przed uczniami, dyrektorów przed pracownikami. Wiele pytań i wiele porad na łamach książek i czasopism dotyczy „właściwego” zachowania wobec osób społecznie obdarzonych wyższą rangą. Dziewczyna organizowała prywatkę i nie przedstawiła gości swojej matce, jak powinna naprawić błąd?; chłopak odbywa staż w PGR, pracuje z panią Stefanią, ona zwraca się do niego po imieniu, więc czy on też może mówić do niej na „ty”, skoro jest 10 lat starsza?; jak się zachować podczas pierwszej wizyty u przyszłej teściowej?; czy na zaproszeniu na ślub należy wypisać tytuły naukowe nowożeńców?; czy kobiety mogą w pracy siedzieć w czapkach, gdy jest zimno?; czy dużo starszą sąsiadkę należy przeprosić, całując ją w rękę?; co założyć, idąc z wizytą do rodziców sympatii, co im przynieść i jak się zachowywać? - to przykładowe dylematy, o których rozstrzygnięcie prosili Grzesia czytelnicy i czytelniczki „Nowej Wsi”.

Poradniki uczą, jak okazywać podporządkowanie i pokorę w tego typu relacjach,jak swoim zachowaniem podkreślać zgodę na obowiązującą w nich nierówność. W odpowiedzi na pytania czytelniczek i czytelników, zachowania te bywają drobiazgowo opisane: czy pracownik powinien wstać, gdy do pokoju wchodzi szef, i kto pierwszy powinien powiedzieć „dzień dobry”; jak powinien zachować się uczeń, gdy spotka na mieście nauczyciela; w jaki sposób zaoferować dyrektorowi kawę; komu wolno, a komu nie wolno proponować 
przejścia na „ty”; czy należy pukać przed wejściem do pokoju rodzica i czy wolno oczekiwać od rodzica, że ten zapuka, nim wejdzie do pokoju córki; jak nie zgodzić się z opinią nauczyciela tak, by go nie urazić - porady w tych sprawach jasno wskazują, że celem poradnictwa z lat 70. jest nauczenie młodych ludzi posłuszeństwa wobec wyższych rangą, nigdy natomiast podważanie sensowności tych rang lub ich przełamywanie. Przestrzeganie hierarchii zakodowanych w wyżej opisanych relacjach autorki i autorzy poradników uważają za niezbywalny element dobrego wychowania. Już sam dystans do nich świadczyłby więc o braku kulturalnego obycia.

$\mathrm{Na}$ tle innych hierarchii społecznych ciekawie prezentuje się postulowany w poradnikach kształt tzw. relacji damsko-męskich. Charakteryzuje go specyficzna niespójność. Poradniki korzystają z konserwatywnego repertuaru genderowych ról, a więc i z klasycznych modeli kontredansu, a wspomnieć należy, że flirt, podryw, zakochanie, „chodzenie ze sobą” to tematy omawiane na łamach poradników niezwykle drobiazgowo i obszernie. Na przykład Ewa na łamach „Filipinki” odradza dziewczynom podrywanie chłopców, wychodzenie z inicjatywą, gdy ktoś im się podoba. Uważa bowiem, że dziewczyny robią to nieumiejętnie, zbyt szybko ujawniając wszystkie swe uczucia, co wystrasza chłopców. W podobnym duchu doradza Jan Kamyczek. „Czy może pierwsza wyznać uczucie dziewczyna? [...] mocno ryzykuje. Podczas gdy dziewczyna zawsze z przyjemnością usłyszy, że jest kochana, i usposabia ją to do wzajemności, przeciętnego chłopca płoszy wyznanie dziewczyny, jeśli jej uczuć w pełni nie podziela, a skąd może wiedzieć, jak z tym jest?” (233) - pisze.

Mnóstwo pytań do redakcji omawianych tu czasopism dotyczy właśnie zachowań odpowiednich dla każdej z płci oraz gestów dozwolonych wobec płci przeciwnej. Grześ pytany był np. o to, czy dziewczynie wypada pierwszej zaprosić do domu chłopaka, którego zna tylko z listów i zdjęć; czy podczas zabawy dziewczyna może odmówić tańca pijanym chłopcom; czy odmówienie chłopcu, by niósł walizkę dziewczynie, obraża go; kto kogo powinien brać pod rękę: chłopak dziewczynę czy dziewczyna chłopaka; czy dziewczynie wypada iść samej do kina; czy dziewczyna może odwiedzić w domu chorego kolegę; co chłopiec ma zrobić ze spinkami do mankietów, które mu się nie podobają, ale dostał je w prezencie od swojej dziewczyny; czy w restauracji chłopcy mogą zamówić pierwsi, nie czekając, aż zamówią koleżanki; jak dziewczyna ma powiedzieć chłopcu, który jej się podoba, by mył ręce itd.

Nic więc dziwnego, że w savoir-vivre'owym poradniku Kamyczek wiele miejsca poświęca tzw. sprawom damsko-męskim. W rozdziale ze słowami na 
"s" pojawia się hasło zaanonsowane nietypowo, bo rysunkiem serca. Hasło to jest niezwykle rozbudowane: ma prawie 20 stron, natomiast inne liczą zazwyczaj pół strony, a niektóre zaledwie kilka zdań. Z rozdziału tego dowiadujemy się m.in., jak kulturalnie dać kosza, jakie są fizjologiczne objawy miłości i jakie strategie wolno obrać wobec miłosnych rywali. Podobnie jak Ewa na łamach „Filipinki”, gdy chodzi o sprawy uczuć, Kamyczek stosuje wobec dziewcząt ton protekcjonalny, żartobliwy, z przymrużeniem oka. „Nie krytykuj jej, nie egzaminuj, nie traktuj z góry dlatego, że zdarzyło jej się pomylić Prousta z Prusem oraz Iran z Irakiem" - doradza Kamyczek zakochanym chłopcom, budując z nimi swoistą komitywę w kontrze do jakoby tajemniczych i nieobliczalnych dziewczą ${ }^{28}$. Ewa z kolei narzeka, że „dziewczęta mają skłonność do przesady", nieracjonalnych zachowań i opinii. Wytyka im, że zamiast trafić w „złoty środek”, reagują nader emocjonalnie, np. narzucając się chłopcom albo przeciwnie: zachowując „jak księżniczki”. Uważa to za cechy typowo kobiece, od których sama się dystansuje - wypunktowując je i karcąc za nie, co przydaje Ewie walorów bezstronnej obserwatorki (mimo że kobiety). Kamyczek - męski pseudonim piszącej poradnik kobiety - także esencjalizuje kobiecość. Przypisuje dziewczętom określone skłonności, które wystarczy odpowiednio stymulować, by pozytywnie zaowocowały w sytuacji kontredansu, magicznie uzupełniając się z podobnie naturalizowaną męskością. „Wykorzystuj jej przyrodzone macierzyńskie ciągoty, niech ci wiąże muszkę, podstrzyga koafiurę [...], niech ma czasem okazję, jeśli są warunki, coś ci ugotować, wszystko to dziewczynie się spodoba, lecz uwaga, bądź niby-dzieckiem chwilami, a w ogóle to nad wiek mężczyzną, oparciem dla niej, zakładem ubezpieczeń i preceptorem (bez piłowania)" - radzi Kamyczek chłopcom ${ }^{29}$.

To właśnie w kontekście kontredansu na łamach socjalistycznych poradników najczęściej pojawiają się hasła nawiązujące do tradycji szlacheckich: honor, rycerskość, gentelman. „Honor w sercowych sprawach to jest: nie podrywać sympatii swojemu przyjacielowi, nie podrywać chłopca swojej przyjaciółce" - wyjaśnia Kamyczek, gdy wymaga, by zachowywać się honorowo ${ }^{30}$. "Człowiek wysokich zalet, dawniej również urodzenia, obecnie po prostu: szlachetny" - definiuje z kolei gentelmana i wymienia przykładowe

28 J. Kamyczek Savoir vivre..., s. 235.

29 Tamże.

30 Tamże, s. 244. 
jego cechy: „szarmancki dla dziewczyn, nie zwala na drugich, dotrzymuje słowa, opiekuje się wdową i sierotą (z dawnego kodeksu rycerza, tu w znaczeniu: na widok zemdlonego dzwoni po pogotowie), z dziewczyną obchodzi się jak z jajkiem, wierny w przyjaźni, oddaje długi, wymaga od siebie"31. O rycerskości często wspomina na łamach „Filipinki” Ewa, zaznaczając, że „nowoczesność bynajmniej rycerskości nie wyklucza”. Rycerskość to zdaniem Ewy cecha zarezerwowana dla mężczyzn, ponieważ objawia się podawaniem ręki kobietom wysiadającym z tramwaju, ułatwianiem założenia palta, całowaniem ich w rękę, opieką nad koleżankami, obroną kobiet przed namolnymi adoratorami. Wszystko to wpisuje Ewa na listę obowiązków chłopców wobec dziewcząt.

Tradycyjnie rozpisanym rolom płciowym w obrębie relacji uczuciowych, miłosnych, intymnych, towarzyszy jednak postulat emancypacji kobiet na szczeblu zawodowym, przedstawianej jako niezbywalny element nowoczesności. Stąd niespójność, o której wcześniej wspomniałam. W adresowanym do dziewcząt poradniku Marii Dankowskiej Wcztery oczy znajdziemy rozdział pod tytułem „Ty także jesteś człowiekiem”, który zaczyna się od słów: „I o tym nigdy nie wolno ci zapomnieć. I nigdy nie pozwól, żeby zapomniał o tym twój chłopiec. Co to znaczy? To znaczy, że i ty, i on musicie nawzajem szanować swoją ludzką godność”. Dalej Dankowska pisze: „Dzisiaj kobieta samotna ani nie dziwaczeje, ani nie staje się śmieszna, bo pracuje zawodowo i na równi z mężczyzną kształtuje swoje życie także w dziedzinie intymnej. [...] Kobieta współczesna nie musi polować na męża, bo swą pozycję, stopę życiową i znaczenie w społeczeństwie zawdzięcza własnej pracy i własnemu stanowisku, a nie pozycji męża"32. Choć w dziedzinie miłosnej hołdujące zasadzie kobiecej bierności wobec mężczyzn, w zakresie pracy i „Filipinka”, i,Nowa Wieś” także stawiają na sprawczość i samodzielność kobiet, namawiając je do zdobycia wykształcenia i za oczywiste biorąc rozpoczęcie przez nie życia zawodowego.

\section{Polityka prorodzinna}

Poradniczemu konserwatyzmowi w dziedzinie flirtu odpowiada konserwatywny cel życia intymnego, który poradnictwo lat 70. konsekruje. Jest nim heteroseksualne małżeństwo i rodzicielstwo. Lektura poradników dla młodzieży pozwala na rekonstrukcję modelu życia, które poradniki te propagują

Tamże, s. 53.

M. Dankowska W cztery oczy..., s. 23. 
i któremu nadają status dobrego, pożądanego, normalnego. Najpierw więc czytelnik/czytelniczka dowie się z nich o społecznych, uczuciowych i seksualnych problemach życia młodzieńczego, ponieważ najprawdopodobniej przeżywa je, gdy sięga po tego typu lekturę albo gdy lekturę tę podsunie mu/jej szkoła lub rodzice. Następnie dowie się, że po trudnym okresie burzy i naporu następuje wypłynięcie na spokojne wody, tzn. założenie rodziny, ta bowiem stabilizuje życie seksualne, uczuciowe i społeczne.

Wyrazem prorodzinnej ideologii było wprowadzenie w 1973 roku do szkół przedmiotu o nazwie: „przysposobienie do życia w rodzinie socjalistycznej”. W tym samym roku przy Ministerstwie Oświaty i Wychowania powstał Instytut Badań nad Młodzieżą. Dziesięć lat później IBnM opublikował raport z badań nad wartością pedagogiczną lekcji z przysposobienia ${ }^{33}$. Okazało się, że zarówno uczniowie, jak i rodzice i nauczyciele ocenili je zasadniczo pozytywnie (ok. 80\% badanych). Ponad 60\% badanych uznało wiedzę zdobytą na lekcjach z przysposobienia za przydatną ${ }^{34}$. Uczniowie podkreślali, że zajęcia tego typu powinien prowadzić dobrze przygotowany nauczyciel, nauczyciele zaś - że lekcje przysposobienia są konieczną alternatywą dla milczenia w rodzinie i wulgaryzmu rówieśników, zwłaszcza w dziedzinie seksualności. Badania wykazały także wpływ zajęć na kształtowanie egalitarnego modelu rodziny, uświadomienie młodzieży społecznej funkcji rodziny, kształtowanie modelu przyszłego męża/przyszłej żony i oczekiwań osobowościowych wobec niego/niej, przygotowanie do pełnienia roli rodzicielskiej w przyszłości, przyswojenie powinności wobec rodziny. Oznacza to, że - podobnie jak poradniki - kształtując modele życiowych trajektorii oraz modelując aspiracje młodych ludzi w zakresie życia prywatnego, przedmiot ten spełniał także funkcję socjalizacyjną w warunkach dynamicznych przemian obyczajowych i społecznych, szybszych niż dojrzewanie jednego pokolenia. Był swego rodzaju erzacem rodziców, instruując dzieci i młodzież w dziedzinach, które wcześniej stanowiły domenę socjalizacji pierwotnej, bazującej na mimowolnej obserwacji i naśladownictwie zwyczajów domowych.

33 B. Czyżkowska, J. Gęsicki Świadomość ideowo-moralna młodzieży i jej kontekst społeczny, w: Z problematyki badań nad młodzieżą. Materiały prezentujqce dorobek badawczy Instytutu Badań nad Młodzieżą w latach 1973-1983, red. F. Iniewski, B. Czyżkowska, M. Balcerek, Instytut Badań nad Młodzieżą. Ministerstwo Oświaty i Wychowania, Warszawa 1983, s. 70-72.

Podobne wnioski wyciągnąć można z wydrukowanych na łamach „Filipinki” prac nadesłanych na ogłoszony W 1973 roku przez czasopismo konkurs: „Między pierwszą a drugą rodziną”. „Filipinka" poprosiła biorących w nim udział czytelników i czytelniczki, by opisali swoje refleksje na temat lekcji przysposobienia do życia w rodzinie socjalistycznej. 


\section{Opowiedz nam swoje życie}

Poradnictwo na łamach „Filipinki” i „Nowej Wsi” wymagało interakcyjności między redakcją a czytelniczkami i czytelnikami. Ewa i Grzesio wielokrotnie wspominali, że listów dostają mnóstwo, tylko część z nich jest drukowana, na inne natomiast odpowiadają prywatnie - zwłaszcza gdy dotyczą one spraw niecierpiących zwłoki. Kilkakrotnie na łamach „Filipinki” Ewa apelowała do autorek i autorów listów, by podawali adres zwrotny, gdyż w kwestiach bieżących nie jest w stanie odpowiadać publicznie, bowiem cykl produkcyjny pisma trwa trzy tygodnie. Wspominała też, że gdyby miała odpisywać na wszystkie listy, to rubryka Jak się zachować radzi Ewa zajęłaby cztery razy więcej miejsca, na co redakcja „Filipinki” nie może sobie pozwolić.

Poradnictwo to jednak nie jest jedyną platformą wymiany między redakcją a czytelniczkami i czytelnikami. W latach 70. oba czasopisma rozpisują liczne konkursy i ankiety, w których namawiają czytelniczki i czytelników, by opisywali wybrane aspekty swojej codzienności. Przedsięwzięciem „Nowej Wsi” był - ogłaszany także w „Filipince” - konkurs „Moje życie w PGR”. Inny konkurs skierowano do osób, które pracę w polu łączyły z pracą w fabryce lub poza rolnictwem - redakcja „Nowej Wsi” prosiła, by opisały one wady i zalety takiej sytuacji. „Moja pierwsza miłość” oraz „Pejzaże wiejskie” to z kolei konkursy na opowiadania. Ich zwycięzcy doczekali się publikacji zgłoszonych do nagrody tekstów. Co roku „Nowa Wieś” organizowała także konkurs „Młody Mistrz Plonów", w którym prezentowane były sylwetki osobno kobiet i mężczyzn pretendujących do tego tytułu. Konkursy „reportaż z mojego miasteczka”,,na wsi w dzień powszedni i w niedzielę”,,wyprawa w świat dorosłych”,,,co to znaczy człowiek odważny?”, „opowieść o moim domu”, ,czy znasz swoich rodziców?", ,pamiętnik literacki” i wiele innych rozpisała z kolei w latach 70. „Filipinka”.W tym samym okresie „Filipinka” zamieszczała na swoich łamach rozliczne i rozbudowane ankiety: „nasz internat”,,,daleko od domu”, ,droga do pracy”, „moja praca”, „nauczyciele, koledzy i ja”, ,wieczory i święta”, „w nowej szkole" itd. Wyniki wszystkich doczekały się obszernych, drukowanych nieraz w odcinkach, omówień i podsumowań - czasem autorstwa dziennikarek/ dziennikarzy, czasem proszonych o to ekspertek/ekspertów z dziedzin, których ankiety dotyczyły.

Inną formą interakcji czasopisma z czytelniczkami i czytelnikami były tzw. kluby: np. Klub Książki „Nowej Wsi”, za pomocą którego czytelnicy/czytelniczki mogli zamawiać publikacje i otrzymywać je pocztą, oraz Klub Poezji „Nowej Wsi”.„Nowa Wieś” przeprowadziła także akcję „20 tysięcy”, w ramach której studenci spotykali się z licealistami i uczniami ostatnich klas szkół 
podstawowych, by pomóc im zdecydować o wyborze kierunku studiów i namówić do dalszego uczenia się. Spotkania te organizowała redakcja NW. Z kolei „Filipinka” tworzyła bank adresów kontaktujący kandydatki i kandydatów na określone kierunki studiów ze studentkami i studentami uczącymi się na tych kierunkach, by drudzy pomogli pierwszym w przygotowaniu się do egzaminów, a także odpowiedzieli na pytania i wątpliwości licealistek i licealistów. Oba czasopisma drukowały również reportaże interwencyjne, podjęte na skutek listów i próśb ze strony czytelniczek/czytelników.

Jeszcze inną formą interakcyjności, do której namawiały redakcje obu czasopism, były kierowane do odbiorczyń i obiorców liczne prośby o informację zwrotną. „Nowa Wieś” prosiła np. o wypełnienie ankiety, w której pytała m.in.: o czym chciałbyś przeczytać w „Nowej Wsi”?; gdyby do Twojej miejscowości przyjechał nasz dziennikarz, co poleciłbyś mu opisać?; o czym sam chciałbyś do „Nowej Wsi” napisać?; gdybyś był redaktorem „Nowej Wsi” to...; jak oceniasz ilustracje w „Nowej Wsi”?; od czego zaczynasz czytanie nowego numeru?; od jak dawna czytasz „Nową Wieś”?; czy masz trudności w zdobyciu pisma? itd. „Filipinka” pytała z kolei o oczekiwania pod swoim adresem w zakresie pomocy w wyborze zawodu. Wydrukowała poświęconą temu tematowi ankietę. Inna ankieta na łamach „Filipinki” nosiła tytuł: „Znamy się? Czy wy nas znacie? Czy my znamy was?”. Znalazły się w niej pytania o ambicje i zainteresowania czytelniczek, a także ich sposoby spędzania wolnego czasu oraz problemy związane z wchodzeniem w dorosłość. Redakcja „Filipinki” rozpisała także konkurs „Filipinki o Filipince”, z prośbą do prenumeratorek, by wyraziły szczere opinie na temat czasopisma.

Wszystkie te formy interakcyjności były zaproszeniem czytelniczek i czytelników do narratywizacji własnego życia: potrzeb, oczekiwań i planów. W ten sposób, modelując socjalistyczny podmiot lat 70., omawiane tu czasopisma wyposażały ów podmiot w autorefleksyjność. Miał on wykuwać się i umacniać poprzez opowiadanie samego siebie: swojego życia i tożsamości w wymiarze pokoleniowym i indywidualnym, zawodowym i intymnym, całościowym i dobowym.

Zaproszenie do autorefleksji i narratywizacji interpretować można na co najmniej cztery sposoby. Po pierwsze, za sprawą opisów życia codziennego w jego czasem najdrobniejszych przejawach, redakcje czasopism zdobywały szczegółowe informacje o swoich odbiorcach i odbiorczyniach, toteż mogły doskonalić skierowaną do nich ofertę czytelniczą. Po drugie, rozliczne ankiety, konkursy i rubryki poradnicze budowały pozór partnerskiej relacji między twórcami i odbiorcami pism. Nazywam to partnerstwo pozornym, 
gdyż moc normotwórczą i ocenną miała tylko jedna jego strona. Autorki i autorzy porad to więc raczej zastępczy rodzice, opiekunowie i nauczyciele, którzy zagospodarowywali rejony nie objęte szkolną ani rodzicielską pieczą, a nie koleżanki, z którymi - przynajmniej czasami - rozmawia się na równej stopie. Po trzecie, uczynienie autonarracji niezbywalnym elementem nowoczesnego podmiotu było wyposażeniem tego podmiotu w narzędzie aktywnego kształtowania swojego losu i kierowania nim, do czego oba czasopisma namawiały. Przekazem obu było bowiem, że życia nie należy „puścić wolno”, zdając się na bieg zdarzeń, lecz trzeba nim kierować. Troskliwie, cierpliwie i nierzadko z mozołem pilnować jego przebiegu, gdyż inaczej ześlizgnie się ono w od wieków żłobione tory klasowej reprodukcji. Oddane w ręce spontaniczności powieli stare scenariusze.

Wreszcie, postulowaną na łamach czasopism autorefleksyjność rozumieć można jako przejaw nowoczesnego dyskursu samorealizacji, a wraz z nim, niepostrzeżonego wejścia kapitalistycznego dyskursu racjonalizacji czasu - w wymiarze całego życia i w wymiarze codzienności. Zaplanowanie życia, zapanowanie nad nim, kontrola życiowej trajektorii - zawodowej (wybór studiów, szkoły, pierwszej pracy itd.), osobistej (narzeczeństwo, małżeństwo, dzieci) i zdrowotnej (higiena, seksuologia) - to z pewnością cele, jakie stawiają przed czytelniczkami i czytelnikami młodzieżowe czasopisma lat 70. Widziane z perspektywy kapitalistycznej, można by określić je mianem zarządzania karierą. Życie jako projekt wymagający zaplanowania i racjonalnej realizacji - ten wzorzec zaskakująco zbliża dyskurs socjalistyczny lat 70. do dyskursu zachodniego tego samego okresu. Pozwala to przypuszczać, że w przynamniej w niektórych aspektach przepaść dzieląca Polskę od krajów kapitalistycznych nie była tak wielka, jak zwykliśmy sądzić.

\section{Koniec szarej strefy}

Poradnictwo lat 70. ogniskowało się wokół trzech tematów: zdrowia i higieny (w tym zdrowia i higieny seksualnej), ścieżki szkolnej i zawodowej oraz postaw ideowych i moralnych (których przejawem miało być dobre wychowanie i biegłość w sztuce savoir-vivre’u). Ucząc i wychowując, poradniki książkowe i poradnictwo na łamach czasopism wytwarzały i propagowały normy dotyczące praktyk i postaw. Normatywny potencjał poradnictwa sprawiał, że od młodych ludzi można było zacząć oczekiwać zachowań zgodnych z tymi, które poradnictwo zalecało. W efekcie życie jednostek zaliczanych do dorastającego pokolenia - zarówno w jego wymiarze dobowym, jak i całościowym 
- stawało się coraz bardziej do przewidzenia. Było niesłychanie drobiazgowo opisane. Zabiegi wokół ciała, zachowanie w szkole, w pracy i w domu, sposoby uczenia się, pracowania i odpoczywania, czas wolny, odpoczynek, wakacje wszystko to zostało na łamach poradników opisane i tym samym poddane normatywizacji. Wymiary ludzkiego życia, które dotąd znajdowały się w szarej strefie codzienności oraz niesformalizowanych relacji międzyludzkich, zostały objęte wskazówkami i zaleceniami. Nawet chodzenie do ubikacji stało się tematem jawnym, omówionym i podlegającym kształtowaniu. A także tym, co może być robione prawidłowo lub nieprawidłowo, co może być zdrowe lub patologiczne. Za sprawą poradnictwa wiele sfer ludzkiego życia zostało zatem poddanych kontroli i medykalizacji. Czynności, praktyki, zwyczaje dotąd indyferentne, po lekturze poradników okazywały się sprawami, które wymagają specjalnego namysłu, starań lub troski. W tym sensie boom poradnictwa z lat 70. można intepretować jako wzmożenie kontroli społecznej za pomocą biopolityki.

Z drugiej jednak strony inflacja opisu codzienności wychodziła naprzeciw potrzebom ogromnej liczby osób, które na skutek urbanizacji i awansu znalazły się w rzeczywistości obcej i potrzebowały wskazówek, jak poruszać się w niej tak, by nie narażać się na niezrozumienie, śmieszność, agresję. Poradnictwo lat 70. mogło dostarczać całym grupom społecznym swoistej instrukcji obsługi codzienności. Tematyzując ową codzienność, czyniąc ją przedmiotem bezpruderyjnego, technicznego opisu, poradniki wspomagały być może proces jej odczarowywania. Nie tylko ułatwiały poruszanie się w nowych przestrzeniach klasowych i miejskich, ale także czyniły z konieczności nauczenia się nowych zwyczajów rzecz zwykłą, oczywistą, nie budzącą sensacji. Zmniejszały tym samym społeczne odium ciążące na „ludziach z awansu". Charakter i trwałość powiązanego z urbanizacją piętna „człowieka z awansu” dobrze oddaje używane dzisiaj pogardliwe określenie „słoiki”, rzucane pod adresem ludzi, którzy przeprowadzili się z małych miejscowości do dużych miast. 


\section{Abstract}

\section{Anna Zawadzka}

THE INSTITUTE OF SLAVIC STUDIES, POLISH ACADEMY OF SCIENCES

The Modern Individual, the Cultured Person: Life Manuals for Young Readers in the 1970s

The Polish publishing market of the 1970s produced a wealth of advice books on topics such as hygiene, manners, interpersonal relationship, sex and family life as well as timemanagement (from day-to-day planning to general life planning). Hygiene manuals, for instance, were used to train children in primary and secondary schools to live in socialist families. Examining the context of life manual writing as a genre, Zawadzka focuses on three aspects - modernisation, urbanisation and class advancement. She also asks what brand of socialism was being promoted in the 1970s, when this type of writing encouraged specific practices and attitudes.

\section{Keywords}

Polish People's Republic, 1970s, life manual writing, modernisation 